\title{
IMBRICAÇ̃̃ES ENTRE A ABERTURA MATERIAL DOS DIREITOS FUNDAMENTAIS E OS APORTES DO DIREITO GLOBAL
}

\section{IMPRINT BETWEEN THE MATERIAL OPENNESS OF CONSTITUTIONAL RIGHTS AND THE CONTRIBUTION OF THE GLOBAL RIGHTS}

\author{
Fausto Santos de Morais \\ faustosmorais@gmail.com \\ José Paulo Schneider dos Santos \\ josepauloschneider@yahoo.com.br \\ Guilherme Pavan Machado \\ g.pavan.machado@gmail.com
}

Recebido: 3-1-2018

Aprovado: 30-7-2020

SUMÁRIO: 1 Introdução. 2 Contextualização histórico-conceitual dos direitos fundamentais. 3 A abertura material dos direitos fundamentais. 3.1 Abertura material à brasileira. 3.2 Exemplificando a abertura material nas decisóes do Supremo Tribunal Federal. 4 Direito global e democracia: as novas roupagens político-jurídicas provenientes da globalização. 5 Consideraçóes finais. 6 Referências

\section{RESUMO:}

A pesquisa teórica recairá sobre a repercussão dos direitos fundamentais reconhecidos pelo artigo $5^{\circ}, \$ 2^{\circ}$, da $\mathrm{CRFB} / 88$ no desenvolvimento das noçóes do direito global. Tem-se como escopo, portanto, apresentar a chamada abertura material dos direitos fundamentais e a sua possível imbricação com o transconstitucionalismo. Buscar-se-á, ademais, (a) revisar na bibliografia o conceito acerca dos direitos fundamentais; (b) estabelecer uma definição da abertura material concatenada

\section{ABSTRACT:}

The theoretical research will relapse on the repercussion of fundamental rights recognized by article $5^{\circ}, ' \$ 2^{\circ}$ of $\mathrm{CRFB} / 88$ in the development of the notions of the global right. The aim is, therefore, to present the called natural opening of fundamental rights and its possible imprint with the transconstitutionalism. Will seek, in addition, (a) to review in the bibliography the concept about the fundamental rights; (b) to establish a definition of material openness linked to the Brazilian legal 
à realidade jurídica brasileira; (c) apresentar o emprego da abertura material dos direitos fundamentais na jurisprudência do Supremo Tribunal Federal; (d) investigar a teoria do direito global. Acredita-se que a pertinência temática e a relevância do presente estudo vêm interiorizadas na proposta de reflexão das condiçóes jurídicas de legitimidade, tutela e concretude dos direitos fundamentais não positivados e sua relação com teoria do direito global.

\section{Palavras-chave:}

Direito global. Direitos Fundamentais. Abertura Material. reality; (c) to present the employment of the material opening of fundamental rights in the jurisprudence of the Federal Supreme Court; (d) to investigate the global law theory. It's believed that the thematic pertinence and relevance of the present study are internalized in the proposal of reflection of the legal conditions of legitimacy, tutelage and concreteness of non-positived fundamental rights and its relation with global law theory.

\section{Keywords:}

Global law. Constitutional Rights. Material Openness of Constitutional Rights.

\section{INTRODUÇÃO}

A teoria dos direitos fundamentais, impulsionada notadamente com o segundo pósguerra, é o cerne de inúmeras pesquisas concentradas no âmbito do Direito. Muitos são os estudos que se destinam a esgotar os elementos envolvendo essa teoria. Propor discussōes sobre direitos fundamentais na atualidade significa circular no campo do alcance, aplicação e restrição desses direitos.

A esse respeito, verifica-se a constante manifestação de novas proposiçóes de direitos fundamentais, moldadas às necessidades da sociedade contemporânea, que transcende as fronteiras do elemento nacional.

Aliás, o judiciário, em especial o Supremo Tribunal Federal (STF), reconhecendo a existência de categorias de valores, princípios e regras, utiliza-se de elementos e critérios jurídicos até então não explorados pelo direito positivo interno para a resolução das contendas a ele trazidas.

Nota-se, deste modo, que o indivíduo contemporâneo é dotado de autonomia outrora não verificada. Tal situação, além de exigir do Estado que atue de forma a respeitar e oportunizar os direitos fundamentais, condicionou o aparecimento de direitos e interesses, por vezes colidentes, entre particulares e redefiniu a questâo da centralização do poder.

A relação náo mais se resume à dicotomia "Estado x indivíduo". Fala-se, agora, em interesses contrapostos entre particulares, o que exige uma posição (de realização e gerência) ativa do Estado e também de outras instituiçóes não estatais. Dito de outro modo, se os contornos mudaram, mudou também o agir do e o artista, isto é, o ente estatal.

Quer dizer, a natureza dinâmica e principiológica dos direitos fundamentais oferece a todo instante uma série de novas problemáticas político-jurídicas. Algumas delas encontram resposta no direito escrito de cada Estado. Outras, exigem do judiciário ampla capacidade hermenêutica e argumentativa, o que provoca constantes (re)avaliçóes e (re)adequaçóes dos mecanismos de tutela dos direitos fundamentais.

De tal sorte, a pesquisa, a partir de uma perspectiva teórico-prática, recairá sobre as seguintes indagaçōes: $\mathrm{O}$ que é um direito fundamental? $\mathrm{O}$ constitucionalismo exerce alguma influência no conceito e aplicaçáo desses direitos? É correto dizer que, no Brasil, os 
direitos fundamentais se resumem aos do catálogo do artigo $5^{\circ}$ da CRFB/88? Fala-se que esses direitos possuem uma abertura semântica e estrutural, por quê? Se em sua essência os direitos fundamentais são direitos abertos, o sistema jurídico que os recepciona também o é? Abertura material dos direitos fundamentais, o que é isto? $\mathrm{O}$ artigo $5^{\circ}, \$ 2^{\circ}$, da $\mathrm{CRFB} / 88$ seria expressão dessa abertura? De que forma o STF tem enfrentado essa temática? Seria essa abertura o canal de irradiação das noçōes globais no direito interno? É possível sustentar uma imbricação entre esse instrumento constitucional e a noção de direito global?

A intenção geral que ora se coloca é: apresentar a abertura material dos direitos fundamentais e sua imbricação com as premissas do direito global. Os objetivos específicos, por sua vez, consistem em: (a) revisar na bibliografia o conceito acerca dos direitos fundamentais; (b) estabelecer uma definição doutrinária da abertura material; (c) apresentar a sua manifestação na jurisprudência do STF; e (d) propor uma conexão entre o elemento global do direito com a doutrina da abertura material.

Assume-se a hipótese de que refletir a respeito da fundamentalidade material dos direitos fundamentais, de onde os direitos humanos são internacionalizados, é pressuposto para a real compreensão das problemáticas atinentes à institucionalização de um direito de cariz global.

A maneira como o trabalho foi pensado e estruturado reclama uma metodologia que possibilite a desconstrução, identificação, qualificação e descrição dos aspectos que permeiam o objeto pesquisado, bem como amplie as possibilidades de interpretaçáo e entendimento dos dados e informaçóes advindas da revisão procedida, a qual tem natureza jurídico-filosófica.

Adotou-se, pois, o método fenomenológico-hermenêutico, cujos aportes contribuem para a sistematização da doutrina e conceitos estudados, bem como o exercício argumentativo a respeito da hipótese defendida.

A justificativa do presente trabalho vem interiorizada na proposta de reflexão de importantes aportes teóricos como pano de fundo para discussóes relativas às condiçóes jurídicas de legitimidade, tutela e concretude dos direitos fundamentais, concatenadas com as exigências de um direito global.

Adverte-se, para fins de justificação da estrutura teórica utilizada, que este trabalho não possui a intenção de reduzir o objeto de estudo às características abaixo individualizadas. Reconhece-se, ademais, que esse tema tem natureza multissecular e sofre interferência de diversas disciplinas. Entende-se, entretanto, que o recorte aqui formulado, muito embora possa significar eventual salto temporal e disciplinar, está em consonância com os objetivos propostos, privilegiando a análise, em bibliografias específicas, da convergência entre as teorias estudadas.

Nessa linha, o presente trabalho foi dividido em três seçóes principais. A seção inaugural é, na verdade, uma contextualização, sob um ponto de vista histórico-conceitual, dos direitos fundamentais. Optou-se por iniciar com essas observaçóes justamente porque elas contribuem para a compreensão da temática desenvolvida nas páginas vindouras. Trazse a lume, na sequência, os seguintes intentos: (i) apresentar a fundamentalidade formal e material dos direitos fundamentais; (ii) conceituar a abertura constitucional brasileira para "novos" direitos fundamentais; (iii) ilustrar a verificação prática do artigo $5^{\circ}, \$ 2^{\circ}$, da CRFB/88 a partir de casos selecionados da jurisprudência do Supremo Tribunal Federal. Busca-se, num terceiro momento, evidenciar a influência globalização na estrutura político jurídica do estado e as tendências de uma democracia calcada em um direito global. Apresentar-se-ão, por fim, as consideraçóes finais, ocasião em que a hipótese de pesquisa será confirmada ou não. 


\section{CONTEXTUALIZAÇÃO HISTÓRICO-CONCEITUAL DOS DIREITOS FUNDAMENTAIS}

Parece razoável, ao menos inicialmente, conceituar os direitos fundamentais como: posiçóes jurídicas, mínimas e impreteríveis, da pessoa humana, positivadas e outorgadas no constitucionalismo intrínseco a cada Estado, cuja finalidade é a proteção de bens proeminentes ou ameaçados (SARLET, 2006, p. 36 e 66) ${ }^{1}$.

Dito de outro modo, "um conceito relativamente simples de direitos fundamentais é o de posições jurídicas essenciais, normalmente garantidas em uma constituição escrita, que protegem o cidadão contra a intervenção dos poderes públicos” (DUQUE, 2014, p.50) ${ }^{2}$.

Não se pode deixar de referir que direitos fundamentais e direitos humanos se apresentam em distintos patamares de positivação ${ }^{3}$, muito embora exista quem defenda que

1 Em posição semelhante, Jorge Miranda enxerga os direitos fundamentais na qualidade de "direito ou [...] posições jurídicas ativas das pessoas enquanto tais, individual ou institucionalmente consideradas, assentes na Constituição, seja na Constituição formal, seja na Constituição material - donde, direitos fundamentais em sentido formal e direitos fundamentais em sentido material" (2012, p. 09-10).

2 Embora pareçam simplistas, tais acepções estão concatenadas com a tradição histórico-institucional e representam as posições juridicas "em face do próprio conceito formal de constituição" (DUQUE, 2014, p.50-51).

3 Uma pesquisa que se coloca a estudar o alcance e realização dos direitos fundamentais necessita, em primeiro lugar, superar a abstração terminológica que cerca seu conceito (DUQUE, 2014, p. 49). Ainda assim, mesmo que terminologia e conceito não sejam sinônimos, não parece nenhum exagero interpretativo pretender, inicialmente, desembaraçar o conceito de direito fundamental do equívoco terminológico por vezes reproduzido na doutrina. Informa-se, desde já, que o termo ora adotado no presente trabalho será "direitos fundamentais". Acredita-se que seu uso atende com coerência as reais significantes desses direitos (DUQUE, 2014, p.50) (SARLET; MARINONI; MITIDIERO, 2012, p. 248). Nesse sentindo, os direitos fundamentais, não raras vezes, são mal concebidos. Aliás, é corriqueiro que esses direitos sejam resumidos àquelas garantias inerentes à pessoa humana. Ou seja, há latente confusão entre diferentes institutos jurídicos. À vista disso, os direitos fundamentais erroneamente são equiparados ou até mesmo recebem a nomenclatura de "direitos do homem", "direitos humanos", "direitos subjetivos públicos", "direitos individuais", "liberdades fundamentais" e "direitos humanos fundamentais" (SARLET, 2006, p.33). Embora conectadas, essas categorias jurídicas possuem caracteristicas particulares. Faz-se necessário, deste modo, individualizar cada uma delas: (i) os direitos do homem são, em sua origem, direitos naturais não positivados ou ainda não positivados; (ii) os direitos humanos têm, em si, traços de direito positivado, isto é, direitos universais perfilhados no direito internacional; (iii) os direitos fundamentais são aqueles direitos outorgados e positivados no interior do direito constitucional de cada Estado, estando sujeitos à classificação dúplice de sua fundamentalidade, formal e materialmente (SARLET, 2006, p. 36). Como se vê, há significativas distinções a respeito das expressões supramencionadas. Por essa razão é que não se pode comparar os direitos fundamentais a categorias não condizentes às suas particularidades. Há de se reconhecer, entretanto, que, aprioristicamente, os direitos fundamentais são, de certo modo, "expressão" dos direitos humanos (SARLET; MARINONI; MITIDIERO, 2012, p. 249) (DUQUE, 2014, p. 52). Vale dizer, "os direitos fundamentais, de certa forma, são também sempre direitos humanos", haja vista que o titular de ambas as categorias, independentemente do modo de representação, é sempre a pessoa (SARLET, 2006, p.35). Todavia, mesmo sendo plausivel aproximálos conceitualmente, não é correto afirmar que os direitos fundamentais são, na mesma proporção, direitos humanos, ou que ambos não representam outro instituto que não os direitos do homem. Ainda que se diga que o reconhecimento institucional jurídico dado aos direitos fundamentais deva ser percebido a partir das noções de liberdade e dignidade da pessoa humana (SARLET, 2006, p. 44), não se pode pretender "resumi-los" à categoria de direitos humanos. Esses últimos, reiterando, têm caráter abrangente, consoante a uma moral juridica universal (SARLET, 2006, p. 36-38). Na verdade, o âmago conceitual dos direitos fundamentais deve ser pensando como consequência do reconhecimento e da legitimidade desses direitos pela ordem constitucional interna. Assim, não se nega que os direitos fundamentais contêm fundamentos e conteúdos morais. Adverte-se, porém, sobre a impossibilidade de percebê-los como simples e acabada demonstração dos direitos humanos (SARLET, 2006, p. 38-39) Uma vez superado o desarranjo terminológico aqui explicitado, o estudo agora passará à análise conceitual dos direitos fundamentais. Buscar-se-á, portanto, evidenciar os indicativos e definições que contribuam com a elaboração dos objetivos propostos. 
as tendências de uma teoria de direito constitucional global ${ }^{4}$ venham a aproximar, ainda mais, essas terminologias.

A propósito, a essência dos direitos fundamentais reclama uma estrutura política integrada da comunidade, de modo que a existência ou não de um direito fundamental guarda relação com o reconhecimento de uma esfera de poder das pessoas frente ao Estado. Do contrário, no autoritarismo, caberia sempre ao ente estatal a última palavra. Isto é, não há direito fundamental sem a representatividade do Estado. Registra-se que é igualmente correto afirmar que esses direitos não sobrevivem a momentos de tirania e absolutismo (MIRANDA, 2012, 09-10), como fora, por exemplo, com Hitler, na primeira metade do século $\mathrm{XX}^{5}$.

4 Paulo Ferreira da Cunha desenvolveu a ideia de uma Constituição, ou melhor, de um direito constitucional universal. Nas palavras do autor "há uma universalização do projecto constitucional mais actualizado e mais progressivo". (CUNHA, 2010, p. 246). Ou seja, "evidentemente, há e haverá ainda certamente durante muito tempo Constituições nacionais. Mas elas acabam já em grande medida por ser (ainda que os constituintes não se dêem conta disso) como que "concretizações", para cada pais, de uma constituição global" (CUNHA, 2010, p. 246). 0 autor toma cuidado para não cometer o ledo engano de afirmar que essa globalização da Constituição já está completada. Em seu magistério, a verdade "é que o internacional e o global já entraram pelas ordens jurídicas nacionais adentro. Em muitos casos, ainda apenas pelas Constituições, e pelos tratados. Mas insistimos: no futuro será normal que os poderes judiciais (e até os outros) invoquem com naturalidade as leis comuns da Humanidade, e efectivamente as apliquem" (CUNHA, 2010, p. 248). À vista disso, é possivel dizer que a disposição do artigo $5^{\circ}, \S 2^{\circ}$, da CRFB/88 corrobora para a leitura de um direito constitucional aberto a interferências internacionais, o que, para Cunha, com o tempo passará de algo incomum e para a condição de regra, isto é, assumirá, de uma vez por todas, a feição de um constitucionalismo global (CUNHA, 2010, p. 245255).

5 Explicando: verifica-se na evolução da tradição jurídica a soberania do Estado na produção de normas jurídicas (BOBBIO, 2006, p. 27). Isto é, através da lei, tem-se a transcrição dos costumes do direito natural para um direito sujeito ao crivo do ente estatal. A transição para o modelo positivista de direito só foi possivel a partir da criação do Estado, que marca o momento de recusa do homem à vida anárquica do estado de natureza. Significa isso que, nas estruturas sociais medievais, cada um era responsável pela defesa de seus bens, inexistindo uma força superior a todos, capaz de constranger cada indivíduo a respeitar as leis. Em suma, o homem abdicou da insegura autogovernação e entregou ao homem (soberano) ou a um conjunto de homens (parlamento) a tarefa de governar sua vida (HOBBES, 1983, p. 105). Ou seja, passou-se do estado de sobrevivência para o de convivência humana, no qual se apresenta como competência do Estado a garantia da paz e a defesa comum (HOBBES, 1983, p. 105-106). Vislumbra-se, assim, a importância da criação do Estado para o direito positivo (e, por consequência, para os direitos fundamentais). Desta forma, quando cada homem transfere parte de sua capacidade de se autogovernar, cria-se um ente com força superior a qualquer individuo isolado, capaz de fazer cumprir as leis. Mais tarde, porém, o Leviatã hobbesiano (o Estado-soberano) se mostrou prejudicial à determinada parte da sociedade. Verdade seja dita, a soberania, antes fundamental à organização da vida humana, passou a obstar as pretensões (liberdade individual e propriedade) do povo. A misericórdia do soberano já não era o bastante. $\mathrm{Na}$ realidade, o Estado, que deveria ordenar o convivio social, estava a privilegiar determinadas classes e, por consequência, prejudicar outras. Assim, o que se precisava era fortalecer e legitimar os direitos, de modo a afastar os arbitrios estatais. 0 homem, então, reivindicou um sistema jurídico que o protegesse dos abusos do Estado (MOLLER, 2011, p. 77). 
Dessa forma, o surgimento dos direitos fundamentais, além de estar ligado ao advento do constitucionalismo ${ }^{6}$, advém da subjetividade da pessoa, no sentido de que a consideração do homem e os direitos das pessoas coletivas (e grupos não personalizados) foram imprescindíveis à construção conceitual desses direitos.

Quer dizer, num primeiro momento, identificam-se apenas expectativas de direitos e normas politicamente declaradas (escritas). Depois, a positivação constitucional contribui para que os direitos deixem de ser simbolicamente fortes para ser normativamente aceitos e respeitados (MIRANDA, 2012, p. 28) ${ }^{7}$.

Com efeito, os direitos fundamentais de cariz liberal se preocupam, ainda que de maneira incipiente, com a relaçấo Estado e indivíduo. É por essa razão que esses direitos (do século XIX) são denominados como direito negativos ou de defesa, "entendidos exclusivamente como limites à ação estatal" (GRIMM, 2007, p 150).

Contudo, essa é uma idealização inicial apenas. $\mathrm{Na}$ verdade, não se pode divorciar o conceito de direito fundamental da relação entre o particular e o Estado. Há de se admitir que através das nuances dessa relação é que as funçôes dos direitos fundamentais vão ganhando novos contornos ${ }^{8}$. Não foi à toa, pois, que Georg Jellinek teorizou a respeito

$6 \quad$ Explica-se que as Constituições representavam o ato de recusa social com momentos de inconstância no cenário político-jurídico. Desse modo, com o surgimento de uma normatividade estruturada, desenvolveramse ideais de não intervenção estatal, direitos de defesa do cidadão frente ao agir do Estado. Em outras palavras, rejeitando o passado de soberania, a sociedade tentou fazer valer posições jurídicas que implicassem a concretização de direitos e liberdades individuais (MIRANDA, 2012, p. 27-28). Marcelo Neves (2010, p. 433434), a esse respeito, destaca a força simbólica dos direitos da pessoa humana, definindo-os como pressupostos ao vigor normativo-constitucional. Em seu ideal, o autor faz crer que as garantias e direitos do homem são produtos da recusa ao contexto jurídico-político absolutista. Assim, na busca pela alternância do papel-função do Estado, as Constituições, a partir do século XVIII, incorporaram o papel de fundamento-base para os governos. Seriam elas o critério último do direito e, desse modo, todos os direitos, especialmente aqueles considerados fundamentais, deveriam estar nela previstos. Ou seja, as Constituições expressavam a noção de "ordem do bem comum", estando o caráter dirigente dos direitos fundamentais diretamente ligados a ela (QUEIROZ, 2010, p. 4748). Queiroz leciona que "os direitos fundamentais são direitos constitucionais, que não devem em primeira linha ser compreendidos apenas numa dimensão técnica de limitação do poder do estado" (2010, p. 47-48). Com efeito, a Constituição, quer "negativa" quer "positiva", assenta um novo limite e redefine o sentido dos imperativos de validade e legalidade. Nesse sentido, adviria da Constituição, em vista de sua vinculação e supremacia, uma feição típica de direito voltada à resolução de conflitos. (QUEIROZ, 2010, p. 48-52).

7 No seu início, as Constituições, principalmente aquelas de vertente liberal-burguesa, foram concebidas diante dos seguintes aspectos rudimentares: (i) a necessidade de limitação do poder estatal; (ii) a garantia de certos direitos fundamentais em face desse poder; (iii) o principio da separação dos poderes (SARLET, 2006, p. 69). Logo, sem garantias asseguradas, bem como na falta da separação dos poderes, não se institucionaliza uma Constituição. Razão pela qual é correto afirmar que os direitos fundamentais alcançaram sua plenitude institucional no interior do Estado constitucional, uma vez que integram um sistema axiológico e atuam como fundamento material de todo ordenamento jurídico (SARLET, 2006, p. 70-72).

$8 \quad$ Fala-se da dinamicidade conceitual comum aos direitos fundamentais. Pensar numa definição de direito fundamental pressupõe reconhecê-lo em diferentes níveis de extensão. Com o segundo pós-guerra, e, portanto, num Estado de direito, surgiu o entendimento de que os direitos fundamentais extrapolam o conceito de direito subjetivos e devem ser percebidos, também, como valores objetivos que norteiam e dão força à ordem constitucional de determinado Estado. Esse direito, segundo Novais, irradia a todos os ramos do direito (enquanto disciplina) e vincula, ou deve vincular, sobre a atuação de todos os poderes estatais. Quer dizer, direitos fundamentais subjetivos fazem referência à relação "Estado e Indivíduo". Direito fundamental objetivo, por seu turno, é aquele que condiz com a universalidade dos direitos, deve ser tido num caráter geral e universal, irradiando-se em todo o ordenamento de um Estado democrático de direito (2010, p.58). 
de três diferentes status dos direitos fundamentais: status negativus; status positivus e status activus (PIEROTH e SCHLINK, 2012, p. 62) ${ }^{9} 10$.

A diferença, entre o aspecto negativo e o positivo dos direitos fundamentais, consiste em saber que, em vista da contemporaneidade e dos reflexos do primeiro e segundo pósguerra, a perspectiva estatal atinge sua definição social, pela qual o Estado deveria "criar e assegurar as condiçóes de liberdade" (PIEROTH e SCHLINK, 2012, p. 68) ${ }^{11} 1213$.

Percebe-se que essa dupla dimensão implica o amplo compromisso do Estado para com os direitos fundamentais. Num primeiro olhar, esses direitos pedem um Estado limitado. Depois, eles aparecem como meios positivos de realização e gozo das garantias inerentes à pessoa humana.

9 Explicando: i) o status negativo faz referência aos direitos de defesa. Ou melhor, direitos que garantem ao cidadão autonomia e liberdade frente ao ente estatal, protegendo-o das "ingerências na liberdade e propriedade" (PIEROTH e SCHLINK, 2012, p. 62). À Lei Fundamental alemã, por exemplo, foram escriturados diversos direitos (negativos) com o fito de proteger o homem do arbitrio e violação estatal (PIEROTH e SCHLINK, 2012, p. 62); ii) a extensão positiva dos direitos fundamentais, por seu turno, reclama a intervenção e a participação do Estado. 0 Estado, que anteriormente deveria deixar o cidadão em paz, é chamado a proteger e materializar as necessidades do povo. Não se quer dizer que o Estado tudo pode. Do contrário, se está a afirmar que a noção objetiva dos direitos fundamentais obriga o ente estatal a executar uma série de ações prestacionais e de segurança ao individuo (PIEROTH e SCHLINK, 2012, p. 63). A Lei Fundamental, neste passo, prevê alguns direitos positivos, dentre eles: direito à proteção, direito à assistência da comunidade, direito à proteção jurídica (PIEROTH e SCHLINK, 2012, p. 63); iii) Já o status ativo dos direitos fundamentais tem significado quando "o particular exerce a sua liberdade no e para o Estado, o ajuda a construir e nele participa" (PIEROTH e SCHLINK, 2012, p. 65). Dizendo de outro modo, o homem não só tem o direito de reclamar autonomia frente ao estado e serviços prestacionais, como também Ihe é assegurado o papel de ator social. Isto é, confere-se ao homem um poder-dever, cuja responsabilidade política implica - ao menos deveria implicar - o aprimoramento da instituição estatal.

10 Queiroz, sobre o mesmo tema, ensina que os direitos fundamentais devem ser percebidos em seus status: passivo (submissão do sujeito ao Estado); negativo (liberdade do homem face ao Estado, ações negativas por parte deste); positivo (dever de realização e proteção estatal); activo (pelo qual o cidadão exerce sua liberdade no e pelo Estado). (2010, p. 55).

11 Quer dizer, o sujeito de direitos deixa de ser mero espectador e passa a atuar ativamente na organização social, naquilo que pode se classificar como a "democratização do poder" (DUQUE, 2014, p.38). 0 resultado disso é o retorno da competição entre os pares. A segurança dos direitos fundamentais, com isso, dependeria não somente da abstenção do Estado (na liberdade individual), mas, essencialmente, da sua participação (como intermediador) na relação privada, donde adviriam as contemporâneas ameaças e ofensas às garantias fundamentais (DUQUE, 2014, p. 38-39).

12 Diferentemente do ocorrido nos modelos americano e francês, o constitucionalismo alemão foi idealizado como "limitação voluntária dos soberanos". Convém esclarecer que o contexto histórico alemão é de tímida superação em relação ao regime monárquico (GRIMM, 2007, p. 153). A adoção do constitucionalismo, no decorrer do século XIX, pela monarquia alemã tinha o objetivo uno de autopreservação da dinastia que se encontrava em "crescente deslegitimação da antiga ordem" (GRIMM, 2007, p. 153). Assim, é na Alemanha que nasce a idealização dos direitos fundamentais "como obrigações positivas do Estado" (GRIMM, 2007, p. 153). A saber, após a assembleia constituinte da República de Weimar (1918), os direitos fundamentais ganham nova roupagem e passam a ser notados como sendo "mais do que direitos puramente negativos" (GRIMM, 2007, p. 154).

13 Verifica-se, a esse respeito, na história da jurisprudência da Corte Constitucional alemã, a paradigmática decisão do caso Lüth (1958). A referida decisão bem traduz a amplitude da extensão dos diretos fundamentais reconhecidos pela Lei Fundamental (Grundgesetz). Aliás, "reconhece[u]-se [com ela] que o Estado está obrigado a agir, na medida do possivel, para a realização dos direitos" (DUQUE, 2014, p.123). Embora a decisão Lüth tenha mantido o Estado como sendo o destinatário dos direitos fundamentais, é de se frisar que ela representa a efetivação desses direitos nas "relações de direito privado" (GRIMM, 2007, p. 155). 


\section{A ABERTURA MATERIAL DOS DIREITOS FUNDAMENTAIS}

As descobertas teóricas a que se chegou até aqui permitem a conclusão de que os direitos fundamentais são direitos, mínimos e inalienáveis, das pessoas, consagrados no ordenamento constitucional de determinado Estado.

É incontroversa, portanto, a relevância do constitucionalismo para o assentamento e legitimidade jurídica dos direitos fundamentais. Não foi à toa a afirmação de que a estruturação dos direitos fundamentais decorre da Constituição. Aliás, a Constituição é o alicerce do Estado e a "ordem do bem comum" (QUEIROZ, 2010, p. 47). Em outras palavras, um documento de inigualável valor jurídico, no qual se tem regulamentada a estrutura do Estado e da sociedade (PARDO, 2005, p. 28).

Ocorre que a própria normatividade estruturada das Constituições, com o passar dos tempos, sofreu significativas refundaçóes em seu conteúdo político-jurídico. Assim, aspectos náo institucionalizados no direito escrito passam a ter papel fundamental no âmbito jurídico.

É com o segundo pós-guerra que se estabelecem discussôes sobre um novo cenário constitucional dos direitos fundamentais, referentes ao conceito, idealização, alcance, força e legitimidade desses direitos. (QUEIROZ, 2010, p. 56). Na Alemanha, desse período, instituíram-se debates acerca de uma teoria hierárquica de valores, a qual pressupóe a ponderação e contrapeso de bens, superando-se, por não mais bastar, o silogismo clássico da justiça (QUEIROZ, 2010, p. 57).

A ser assim, "os direitos fundamentais seriam o vínculo e o manancial dessas inovações e alternativas” (QUEIROZ, 2010 p. 60). O que se quer afirmar é que os perigos de restriçẫo e violação dos direitos fundamentais são percebidos numa lógica evolutiva e de alta dinamicidade, situação que exige dos direitos fundamentais a mesma qualidade. Isto é, com novas ameaças, fazem-se necessários novos mecanismos de defesa dos direitos fundamentais.

Esse é o ponto de partida para uma abertura dos direitos fundamentais: sua não estaticidade. Enfim, as posiçóes jurídicas fundamentais, por si, exigem uma tutela (sobretudo jurisdicional) flexível e aberta (QUEIROZ, 2010, p. 61-62).

Robert Alexy, um dos mais influentes teóricos dos direitos fundamentais na atualidade, ensina que as normas de direitos fundamentais são compostas de "fundamentalidade formal" e "fundamentalidade substancial" (material). Adverte ele para uma imbricação entre essas características e a divisão dos modelos de Constituição "puramente procedimental” (formal) e de Constituição "puramente material” (2011, p. 520).

Por esse ângulo, falar em modelo constitucional formal (ou "puramente procedimental") significa dizer que as normas constitucionais são revestidas de caráter organizacional. A rigor, a Constituição não representa óbice a nenhum elemento "como um possível conteúdo do direito positivo". Para ser direito positivo, portanto, basta ter sido criado de acordo com o procedimento e forma estabelecida (ALEXY, 2011, p. 520). No modelo procedimental de Constituição, ademais, "o conteúdo das leis é decisivamente definido pela vontade do legislador, pela sua racionalidade ou irracionalidade, bem como pelos limites de suas possibilidades de ação" (ALEXY, 2011, p. 521).

Os direitos fundamentais, nesse contexto, como institutos outorgados nos textos constitucionais (de cariz procedimental), não sujeitariam o órgão legiferante. Ao revés, a ele estariam sujeitos, no sentido de que o legislador seria legitimado a interferir nos direitos fundamentais da maneira que bem entendesse (ALEXY, 2011, p. 521). 
Já a Constituição material seria aquela permeada de normas materiais, "a partir das quais pode ser derivado o conteúdo de qualquer norma do sistema jurídico, por meio de um método operacional qualquer" (ALEXY, 2011, p. 521). A lei, nesse alvitre, desempenharia apenas a função declaratória de um dever e/ou obrigação constitucionalmente concebidos. Para Alexy, "aquilo que no modelo puramente procedimental (formal) deve ser solucionado por meio de uma decisão no âmbito da constituição tem que ocorrer no modelo puramente material por meio de uma cognição de seu conteúdo" (2011, p. 521) ${ }^{14}$.

Em sentido semelhante, David Wilson de Abreu Pardo, ao procurar a justificação e aplicação dos direitos fundamentais não enumerados no ordenamento constitucional, destaca a interação entre a noção de Constituição formal e material e a extensão formal e material desses direitos (2005, p. 24-35) ${ }^{15}$.

Logo, mesmo a Constituição, documento de inestimável valor, deve estar aberta às alternâncias político-jurídicas de tempo e espaço. Assim, se a Constituição, que é pressuposto aos direitos fundamentais, admite a interferência de direitos nela não escritos, não haveria justificativa para que o mesmo não ocorresse com os direitos fundamentais ${ }^{16}$.

As normas de direitos fundamentais formais, com efeito, "decorre[m] da sua posição no ápice da estrutura escalonada do ordenamento jurídico” e estão dirigidas (vinculam) a todos os poderes do Estado (executivo, legislativo e judiciário). (ALEXY, 2011, p. 520). Aliás, "o fato de as normas de direitos fundamentais estabelecerem os conteúdos constitucionalmente necessários e impossíveis para o sistema jurídico constitui o núcleo da fundamentalidade formal desses direitos" (ALEXY, 2011, p. 522).

Portanto, direitos fundamentais formais são aquelas posiçóes jurídicas subjetivas positivadas na Constituiçấo, que somente podem ser revisadas, modificadas ou eliminadas

14 Cumpre esclarecer que a concepção de Alexy a despeito de uma "Constituição mista", isto é, prodecimental e material, guarda relação com a vigência das normas de direitos fundamentais. Ou seja, a partir dessa vigência é que "o sistema jurídico [ganha] a natureza de um sistema [...] substancialmente determinado por meio da Constituição" (2011, p. 543). Quer dizer, as normas de direitos fundamentais, cuja natureza principiológica é semântica e estruturalmente aberta, por irradiarem a todos os âmbitos do direito, fazem com que o próprio sistema jurídico adquira um caráter aberto, o que, segundo Alexy, reclama um procedimento racional de sopesamento (2011, p. 543-544).

150 referido autor, valendo-se dos magistérios de Canotilho, J.H. Meirelles Teixeira e Otto Bachof aponta alguns elementos de diferenciação entre Constituição formal e Constituição material. Segundo ele, a primeira diz respeito a normas e princípios outorgados de maneira solene, que, como tal, não permite que seu conteúdo seja elaborado ou alterado senão através dos mecanismos e processos previstos no próprio texto. 0 sentido material, por seu turno, faz referência às normas e aos institutos jurídicos que cuidam da estrutura, atribuição e competência dos órgãos estatais, bem como da instituição e posição do Estado e da sociedade. Tal sentido é permeado de "princípios constitutivos de toda e qualquer ordem jurídica", ainda que não explicitados (formalmente) no corpo da Constituição (2005, p. 29-32).

16 Queiroz (2010, p.106-107), no que concerne a esta temática, reconhece a existência de direitos fundamentais, prima facie, não positivados no direito constitucional interno de determinado Estado. Bem refere a autora lusitana que esses direitos podem ser tidos sob diferentes nomenclaturas: (i) direitos fundamentais extraconstitucionais (CANOTILHO); (ii) direito fundamental em sentido material (MIRANDA); iii) sub-constitutional rule-making (MONAGHAN). A autora, no que the diz respeito, utilizando-se da terminologia dworkiniana, classifica os direitos fundamentais em enumerados e não enumerados. A diferença entre eles consiste em saber que (a) os enumerados estão estabelecidos (escriturados) na Constituição; (b) os não enumerados, por seu lado, encontram-se consignados pelos órgãos responsáveis pela aplicação do direito (leia-se legislativo e judiciário). Em que pese esses últimos não estejam expressamente estabelecidos na Constituição, se previamente pensados pelo legislador, possuem o mesmo valor constitucional que os direitos escriturados no texto constitucional (2010, p.106-107). Interpretação parecida é encontrada nas lições de Sarlet. Para ele, o caráter material faz referência àqueles "direitos que, por seu conteúdo ou substância, pertencem ao corpo fundamental da Constituição de um Estado, mesmo não constando no catálogo". (2006, p. 93). Ou melhor, direitos que não foram previstos expressamente pelo constituinte, mas podem ser percebidos indiretamente via dedução (2006, p. 93). 
via controle de constitucionalidade. No entanto, esses direitos, mesmo que positivados formalmente, quando interpretados, recebem influência do restante das normas constitucionais. Por isso, todo direito fundamental escrito numa Constituição será formal e material em sua fundamentalidade (MIRANDA, 2012, p. 10-11).

Explicando: direito fundamental formal, em um primeiro olhar, está diretamente relacionado com o direito material, pois, dele recebe influência. No entanto, difere-se por ser um direito positivo inscrito na Constituição, ao passo que os direitos fundamentais materiais são direito positivos, ainda que com natureza de direitos naturais, não previstos pelo constituinte (MIRANDA, 2012, p. 12-13) ${ }^{17}$.

Denota-se que "o catálogo de direitos compreende uma rede de princípios, uns extremamente concretos, outros mais abstractos", os quais caracterizam um ideal político. Diga-se de passagem, direitos existem fora e dentro do ordenamento jurídico (QUEIROZ, 2010, p. 113). Por derradeiro, os direitos fundamentais possuem qualidade dúplice. Sob um ponto de vista específico, apresentam-se como direitos constitucionais, isto é, com natureza jurídica constitucional. De outra banda, representam direitos político-normativos, no sentido que sua verificação se dá, também, antes e fora do texto constitucional escrito (QUEIROZ, 2010, p. 114).

Salienta-se que os direitos fundamentais não escritos são legítimos e que de há muito encontram respaldo na ordem normativa constitucional, por exemplo: (i) a Constituição dos Estados Unidos da América, após aditamento em 1791, reconheceu que o fato de alguns direitos estarem expressos na Constituição (positivados) não exclui os direitos, até então, consagrados pelo povo; (ii) a Constituição portuguesa, em seu artigo 16º, n1, dispõe que os direitos fundamentais nela escritos não excluem outros constantes nas leis e regras de tratado internacional; (iii) o artigo $5^{\circ}, \$ 2^{\circ}$, da Constituição brasileira prevê que os direitos nela previstos não excluem outros direitos decorrentes do regime e princípios por ela adotados, bem como os direitos oriundos de tratados internacionais dos quais faça parte o Brasil (MIRANDA, 2012, p. 13).

Ainda, as Constituiçóes da Argentina (art. 33), do Peru (art. 4), da Guatemala (art. 44) e da Venezuela (art. 50), de certa forma, estão expressamente abertas à extensão material dos direitos fundamentais. Aliás, a Lei Fundamental germânica (art. 2) reconhece direitos e garantias análogas aos direitos fundamentais previstos expressamente em seu art. 93, I, no 4. (SARLET, 2006, p. 93)

Com efeito, reconhecer o caráter material dos direitos fundamentais é o mesmo que dizer que "há [ou pode haver] normas de Direito ordinário, interno e internacional, atributivas de direitos equiparados aos constantes de normas constitucionais" (MIRANDA, 2012, p. 13).

A positivação dos direitos fundamentais no texto constitucional e a dinamicidade intrínseca a esses direitos inaugura um caráter duplo de fundamentação (formal e material), do qual a exegese constitucional vem reconhecendo direitos além da simples expressão literal das disposições constitucionais (MIRANDA, 2012, p. 14). Em realidade, diante da sua

17 Não é nenhum exagero esclarecer que, para Miranda, o conteúdo material de um direito é dependente das concepções de direito, concepções políticas e circunstâncias de cada momento e lugar. Assim, direito fundamental não é, tão-somente, aquilo declarado pelo legislador como tal. Então, direito natural - e de vocação comuns a todos - é o cerne para a ideia de direito fundamental ou inerente à pessoa humana. Além disso, mesmo esses direitos oriundos da natureza humana são limitados e, por isso, sua existência não significaria, por si, uma abertura ao relativismo. Isto é, não é pelo simples fato de existir um direito natural que ele será fundamental. Se este, por exemplo, negar outro que deveria ser reconhecido, não terá essa característica fundamental. (2012, p. 12-13). 
dupla fundamentalidade, os direitos fundamentais encontram-se disseminados em todos os setores da vida humana, mas, sobretudo, "desempenham um papel central no sistema jurídico" (ALEXY, 2011, p 523).

\subsection{ABERTURA MATERIAL À BRASILEIRA}

No Brasil, da mesma forma, não se pode falar em um sistema constitucional autônomo e fechado de direitos fundamentais. São verificados direitos fundamentais positivados e espalhados em diferentes partes da Constituição. Além disso, o artigo $5^{\circ}, \$ 2^{\circ}$, da CRFB/88 prevê uma caracterização materialmente aberta dos direitos fundamentais. $\mathrm{Ou}$ seja, consideram-se fundamentais, para além daqueles previstos no catálogo do artigo $5^{\circ}$, os direitos e garantias oriundos do regime e princípios adotados pela Constituição, além dos direitos fundamentais constantes nos tratados internacionais dos quais o Brasil faça parte. (SARLET, 2006, p. 83)

Os direitos fundamentais positivados (formais) na Constituição devem ser analisados como uma parte de toda a ramificação constitucional e, como tais, devem ser interpretados a partir dos princípios espalhados por toda sua extensão. E é desse exercício interpretativo que surgem os direitos fundamentais não escritos (materiais), balizados numa principiologia total da Magna Carta. (SARLET, 2006, p.85)

Desmistifica-se, dessa maneira, a completude conceitual dos direitos fundamentais, devendo ser percebidos num sistema aberto, com tendência para novos conteúdos integrados ao restante do empreendimento constitucional. (SARLET, 2006, p. 86)

Para Sarlet, a diferença dos dois patamares de fundamentalidade é que (a) direitos fundamentais formais são todas aquelas posiçôes jurídicas do indivíduo - em suas dimensóes individual, coletiva e social - que foram previstas expressamente pelo constituinte e, depois, no catálogo do artigo $5^{\circ}$ da Constituição brasileira; (b) os direitos fundamentais materiais, por sua vez, são direitos que, em razão da relevância de seu conteúdo, se equiparam aos direitos consagrados pelo texto constitucional (2006, p. 95).

Em outros dizeres, a Constituição brasileira dá causa para direitos não escritos, não reconhecidos pelo direito positivado, mas implícitos e subentendidos nas normas constitucionais, bem como nos direitos fundamentais decorrentes do regime e princípios (SARLET, 2006, p. 102). Quando o reconhecimento de um direito não positivado corresponder às exigências do sistema constitucional, deve ser ele considerado um direito fundamental, e essa sua fundamentalidade, ainda que material, deve vincular positivamente a atuação dos órgãos jurisdicionais (SARLET, 2006, p. 105).

Esclarece-se que direito fundamental implícito é aquele direito não escrito, mas que está subentendido nas normas constante no catálogo de direito fundamentais; extrai-se do texto o que nele já consta implicitamente (SARLET, 2006, p. 107). Agora, aqueles direitos decorrentes, fora do catálogo, só poderão a estes serem comparados se relevantes substancialmente em seus conteúdos, de modo que se revelem posições jurídicas cruciais esquecidas ou não pensadas pelo legislador.

Sarlet, nesse sentido, diz que a cláusula de abertura não conduz ao entendimento de que todo e qualquer princípio enseja um direito fundamental (equiparado ou de fundamentalidade material). Conclui-se, assim, pela existência de posiçóes jurídicas não constantes no interior do catálogo escrito de direitos fundamentais. Todavia, para Sarlet, seu aparecimento deve advir da dedução direta dos princípios constantes no título I, artigos 1 a 4, da CRFB/88 (2006, p. 109-110). 

estudada.

Ver-se-á, na sequência, a exemplificação jurisprudencial da categoria até aqui

\subsection{EXEMPLIFICANDO A ABERTURA MATERIAL NAS DECISÕES DO SUPREMO TRIBUNAL FEDERAL}

O trabalho até o presente momento foi desenvolvido num âmbito essencialmente dogmático. Agora, o foco recai sobre a práxis da abertura material. A intenção é a de tornar evidente o reconhecimento judicial de direitos fundamentais originariamente não escritos na Constituição brasileira, notadamente a partir de casos selecionados da jurisprudência do Supremo Tribunal Federal.

Salienta-se que a abordagem será jurisprudencial e concentrará seus esforços especificamente na análise de julgados do STF, não sendo o objetivo, nos limites aqui instituídos, traçar objeçôes críticas ou avaliar o mérito das decisóes.

Considerando que o trabalho propóe questôes relativas à aplicabilidade dos direitos fundamentais, parece adequado que a análise recaia sobre os julgados daquele que é conhecido por ser o guardião da Constituição. Todavia, isso não significa que as decisóes das outras instâncias e graus jurisdicionais são menos relevantes.

Assim, para o desenvolvimento dos propósitos ora apresentados, optou-se pela seleção de casos contidos no sítio eletrônico do STF, especificamente na parte denominada "A Constituição e o Supremo", que é, na realidade, um compilado de decisóes proferidas ao longo da história institucional do STF, organizado de modo a contemplar artigo por artigo da Constituição brasileira. Informa-se, portanto, que serão consideradas apenas aquelas decisóes associadas à aplicação do artigo $5^{\circ}, \$ 2^{\circ}$, da $\mathrm{CRFB} / 88^{18}$.

Dito isso, destaca-se, por primeiro, a ADI 939, julgada em 15/12/1993 e publicada no DJ 18/03/1994, cuja relatoria esteve a cargo do Ministro Sydney Sanches. Discutiu-se, naquela oportunidade, a constitucionalidade da EC n. 3/93 e da LC n. 77/93. Esse julgado, diga-se de passagem, é considerado paradigmático no que tange à aplicabilidade da abertura constitucional do artigo $5^{\circ}, \$ 2^{\circ}$, da CRFB/88 (VIEIRA, 1999, p. 165).

Tratando de matéria tributária, o STF estendeu a fundamentalidade material para direitos não escritos no catálogo do artigo $5^{\circ}$. Importa registrar que na referida ação, que, insiste-se, representou significativo avanço jurisprudencial e consagrou a abertura material dos direitos fundamentais da Constituição brasileira (SARLET, 2006, p. 94), foi reconhecida a fundamentalidade material da anterioridade (artigo 150, inciso III, da CRFB/88).

Explicando: A EC n. 3/93 e a LC n. 77/93, que instituíram o imposto provisório sobre movimentação financeira (IPMF) e autorizaram a cobrança direta dessa exação, transpassou as exigências da anterioridade (do artigo150, inciso III, da CRFB/88).

Analisando a demanda, o STF entendeu que a anterioridade goza de status de norma de direito fundamental e, como tal, é imbuída de aplicabilidade direta (artigo $5^{\circ}, \$ 1^{\circ}$, da $\mathrm{CRFB} / 88$ ) e tem imunidade a alterações e emendas constitucionais (artigo 60, $\$ 4^{\circ}$, da

18 Seria utópico e irresponsável pretender, nos limites deste trabalho, o estudo de todos os julgados do STF concernentes à temática. Faz-se necessário explicar, por isso, que pela quantidade de decisões encontradas e também pela extensão de algumas, foi preciso verdadeiramente "escolher" as que seriam ou não exibidas. Essa escolha foi pautada no seguinte critério: mesclar o estudo de decisões paradigmáticas com decisões, por vezes, não mencionadas pela doutrina. Além disso, foi dada prioridade para decisões que, de certa maneira, comtemplem o teor daquelas não individualizadas. Explica-se, também, que, a rigor, o conteúdo aqui transcrito será extraído das próprias decisões analisadas, as quais obviamente estarão individualizadas e citadas nas referências. 
$\mathrm{CRFB} / 88)$. Isso porque, muito embora não conste expressamente mencionada no artigo $5^{\circ}$ da Constituição, decorre do regime e dos princípios adotados pela Carta Maior, consoante ao exposto no $\$ 2^{\circ}$ do referido artigo.

Tem-se, de outra banda, o HC 88.420, de relatoria do Ministro Ricardo Lewandoski, julgado em 17/04/2007 e publicado no DJ em 08/06/2007. Havia, nesse caso, um confronto normativo. De um lado, o direito ao duplo grau de jurisdição, escriturado no artigo $8^{\circ}, 2$, $\mathrm{h}$, do Pacto de São José da Costa Rica, incorporado à ordem constitucional brasileira através da exegese do artigo $5^{\circ}, \$ 2^{\circ}$, da CRFB/88, e, de outro, o (hoje revogado) artigo 594 do $\mathrm{CPP}{ }^{19}$, o qual exigia o prévio encarceramento do condenado em sentença criminal como condição para exercer o direito de apelar.

Após sucessivos recursos, a questão foi encaminhada ao STF, sob o argumento de que o fato de a lei processual penal condicionar o reconhecimento da apelaçáo ao recolhimento prévio do condenado a prisão fere o direito ao duplo grau de jurisdição, que ganharia status de norma de direito fundamental, pois teria sido integralizado ao sistema jurídico brasileiro através da abertura material. Além disso, se sustentou que o aludido artigo do CPP estaria revogado pelo Pacto de São José da Costa Rica.

Consignou-se, na mencionada decisão, que o duplo grau de jurisdição, em que pese carecesse de menção direta no texto da CRFB/88, "tem estrutura constitucional" (BRASIL, 2007, p. 438), isto é, é parte integrante "do sistema pátrio de direitos e garantias fundamentais" (BRASIL, 2007, p. 439), porque decorre da interpretação do catálogo dos direitos fundamentais, bem como pelo fato de que esse direito está garantindo em tratado internacional sobre direitos fundamentais (artigo $5^{\circ}, \$ 2^{\circ}$ da CRFB/88).

Faz-se necessário alertar que a decisão possui outros argumentos também relevantes. Para os objetivos ora colocados, entretanto, basta evidenciar aspectos no tocante à abertura material dos direitos fundamentais, o que, aliás, ficou cristalino quando o STF firmou entendimento no sentido de que, por estar garantido em tratado internacional, que versa sobre direitos fundamentais, o duplo grau de jurisdição prevaleceria ao disposto no artigo 594 do CPP. Em outras palavras, o que o STF fez foi atribuir a fundamentalidade material ao direito ao duplo grau de jurisdição.

Todavia, nem sempre o STF reconheceu a fundamentalidade de direitos extrapositivados, como é o caso, por exemplo, do RE 214.349-9, julgado em 13/04/1999 e publicado no DJ em 11/06/1999, tendo como relator o Ministro Moreira Alves, bem como o RE 297.901-5, julgado em 07/03/2006 e publicado no DJ em 31/03/2006, de relatoria da Ministra Ellen Gracie.

Em ambos os julgados, o STF foi questionado quanto à aplicação do CDC em açóes indenizatórias demandadas contra empresas de transporte aéreo. Indagou-se, naquela ocasião, se essa aplicação afrontaria o disposto no artigo 223 da Convenção de Varsóvia e nos artigos $5^{\circ}, \$ 2^{\circ}$, e 178 , da $C R F B / 88$. A controvérsia jurídica, nos dois casos, residia no âmbito do prazo prescricional e de qual legislação aplicar. Tinha-se, de um lado, a prescrição estabelecida no CDC ( 5 anos) e, de outro, a prevista na Convenção de Varsóvia (2 anos).

Para o STF, a precedência do CDC sobre a Convenção de Varsóvia em nada afeta o artigo $5^{\circ}, \$ 2^{\circ}$, uma vez que tal preceito estende-se apenas aos tratados internacionais de direitos fundamentais e não alcança, portanto, a citada Convenção. Acontece que a

190 artigo 594 do Código de Processo Penal, que foi revogado pela lei 11.719/2008, apresentava a seguinte redação legal: 0 réu não poderá apelar sem recolher-se à prisão, ou prestar fiança, salvo se for primário e de bons antecedentes, assim reconhecido na sentença condenatória, ou condenado por crime de que se livre solto (BRASIL, 1941). 
Convenção de Varsóvia trata relativamente da limitação da responsabilidade civil do transportador aéreo internacional, e não de direitos fundamentais.

Com efeito, em conformidade com a interpretação do Supremo, as normas constantes nela, Convenção de Varsóvia, não são normas abertas à fundamentalidade material de que trata o $\$ 2^{\circ}$, do artigo $5^{\circ}$, da CRFB/88. Quer dizer, embora a CRFB/88 abra sua interpretação no dispositivo supramencionado, não é de todo e qualquer tratado que podem surgir os direitos fundamentais não escritos ou não positivados na Constituição, mas somente daqueles tratados internacionais cujo objeto sejam as normas de direitos fundamentais.

Assim sendo, o RE 214.349-9 não foi conhecido pelo STF. Primeiro, porque não houve prequestionamento das "questóes relativas aos artigos (sic) 5\%, II, 93, IX e 178 da Constituição Federal” (BRASIL, 1999, p. 401). Depois, porque, quanto à alegada afronta ao $\$ 2^{\circ}$, do artigo $5^{\circ}$, da CRFB/88, matéria devidamente prequestionada, "ela não ocorre, porquanto esse dispositivo se refere a tratados internacionais relativos a direitos fundamentais, o que não é matéria objeto da Convenção de Varsóvia" (BRASIL, 1999, p. 401).

Já quando do julgamento do RE 297.901-5, embora tenha adotado entendimento idêntico ao acima transcrito no tocante à ofensa ao artigo $5^{\circ}, \$ 2^{\circ}$, da CRFB/88, o STF conheceu e deu provimento ao argumento de que a norma a ser aplicada era aquela constante na Convenção de Varsóvia, conforme consignado no artigo 178 também da CRFB/88, matéria, que neste caso específico, não restou prejudicada por ausência de prequestionamento.

Há, em sentido parecido com o teor do HC 88.420 (antes evidenciado), o HC 94.404, julgado em 18/11/2008 e publicado no DJE em 18/06/2010, cujo relator foi o Ministro Celso de Mello, no qual o STF reafirmou que o status de direito fundamental - ou melhor: a fundamentalidade material - não advém de tratados indeterminados, mas, tãosomente, daqueles relativos a direitos fundamentais ( $\$ 2^{\circ}$, do artigo $5^{\circ}$, da CRFB).

$\mathrm{O}$ mesmo se aplica à equiparação hierárquica das normas de tratados sobre direitos humanos às normas constitucionais $\left(\$ 3^{\circ}\right.$, do artigo $5^{\circ}$, da $\mathrm{CRFB} / 88$ ). Significa isso que, em não se tratando de normas decorrentes de tratados sobre direitos humanos e/ou direitos fundamentais, reitere-se, integradas ao sistema jurídico pelo artigo $5^{\circ}, \$ 2^{\circ}$ e $\$ 3^{\circ}$, $\mathrm{da} \mathrm{CRFB} / 88$, os dispositivos devem necessariamente estar vinculados aos mandamentos constitucionais.

Aliás, ainda segundo a decisão analisada, o legislador, ao considerar tais dispositivos, deve se basear em padróes de razoabilidade, que, na verdade, se apresentam como limitação material da ação do órgão legiferante. Não obstante, assentou-se, a respeito da inconstitucionalidade do artigo 70 da Lei 9034/95, matéria também tratada no habeas corpus em apreço, que a proporcionalidade, "enquanto categoria fundamental de limitação dos excessos do Estado, atua como verdadeiro parâmetro de aferição da própria constitucionalidade material dos atos estatais" (BRASIL, 2008, p. 385).

Outra decisão acerca da qual cumpre tecer alguns comentários é a do AgR do $\mathrm{MI}$ 772, julgada em 24/10/2007 e publicada no DJ em 20.03.2009, cuja relatoria esteve a cargo do Ministro Celso de Mello.

Trata-se de um agravo regimental contra a decisão que não conheceu a ação de MI por incapacidade postulatória da parte recorrente. Naquela ocasião, firmou-se o juízo de que, na controvérsia entre direito de petição e capacidade postulatória, se sobressai o artigo 133 da CRFB/88, que estabelece que o advogado é indispensável à administração da justiça. 
De tal sorte, o agravo também não foi conhecido, novamente pela ausência de capacidade postulatória ao recorrente, que por não ser advogado não tem direito de recorrer em causa própria, sendo que o direito à petição não altera essa incapacidade.

Sobre esse ponto, o STF considerou a "irrecusável supremacia da Constituição Federal sobre todos os tratados internacionais celebrados pelo Estado brasileiro" (BRASIL, 2007, p. 61), isto é, entendeu o Supremo, no caso em tela, que "nenhum valor jurídico terá o tratado internacional, que, incorporado ao sistema de direito positivo interno, transgredir, formal ou materialmente, o texto da Carta Política" (BRASIL, 2007, p. 62), salvo aqueles tratados sobre os quais versam o $\$ 2^{\circ}$ e o $\$ 3^{\circ}$, do artigo $5^{\circ}$, da CRFB/88.

$\mathrm{Na}$ verdade, ponderou-se quanto à inocorrência de uma "precedência hierárquiconormativa” dos tratados internacionais. A propósito, essa problemática ganhou novos contornos com a EC 45, que trouxe a denominada "cláusula de equivalência dos tratados e convençóes internacionais sobre direitos humanos com as emendas constitucionais" (BRASIL, 2007, p. 64), desde que notado o procedimento do $\$ 3^{\circ}$, do artigo $5^{\circ}$, da $\mathrm{CRFB} / 88^{20}$.

À semelhança do que ocorre quando se olha para o teor do HC 88.420 e do HC 94.404, é possível deduzir que: as normas que recebem a extensão material da fundamentalidade não surgem de todo e qualquer tratado.

Pretendeu-se, de modo inaugural, colocar em evidência que passados aproximadamente cinco anos da promulgação da Constituição de 1988, o STF - no julgamento da ADI 939 - inaugurou a aplicação jurídica da abertura material dos direitos fundamentais prevista no texto constitucional. Logo, foi uma decisão num momento de consolidação da nova ordem constitucional. E por essa razão é que se optou por iniciar a apresentação a partir deste exemplo.

A propósito, à medida que a Constituição se aproxima do seu aniversário de 30 anos, enxerga-se o quão modificado está o contexto político-jurídico brasileiro. $\mathrm{O}$ desenvolvimento da economia e da sociedade em geral exige corriqueiramente do direito uma nova interpretação, um novo dizer.

Ou seja: vive-se num Estado de direito. Na verdade, num Estado democrático de e por direito. Acontece que, como um meio de regular a vida humana, o direito náo pode ser estático ou acabado. Pelo contrário, deve ser dinâmico e aberto, razão pela qual o STF, enquanto um órgão que cuida para que as interpretaçóes e argumentaçôes jurídicas do cotidiano estejam em consonância com a hermenêutica constitucional, ganha destacada importância. Nas palavras do ministro Luiz Fux, é dizer que: "se a sociedade evoluiu, o direito evolui, e a Suprema Corte evolui junto, porque ela é a intérprete maior desse direito que transcende aos limites intersubjetivos de um litígio entre partes" (BRASIL, 2011, p. 692).

Assim, até para materializar o que se acaba de dizer, se encerra a exposição aqui realizada com um dos mais importantes julgados da história do Supremo, em que os Ministros, por votação unânime ${ }^{21}$, tutelando os direitos fundamentais formal e materialmente previstos

20 In verbis: Art. $5^{\circ}$ - Todos são iguais perante a lei, sem distinção de qualquer natureza, garantindo-se aos brasileiros e aos estrangeiros residentes no Pais a inviolabilidade do direito à vida, à liberdade, à igualdade, à segurança e à propriedade, nos termos seguintes: [...] \& $3^{\circ}$ Os tratados e convenções internacionais sobre direitos humanos que forem aprovados, em cada Casa do Congresso Nacional, em dois turnos, por três quintos dos votos dos respectivos membros, serão equivalentes às emendas constitucionais. (BRASIL, 1988).

21 Quando se fala que a votação foi unânime, isso quer dizer que o resultado alcançado por todos os ministros foi no mesmo sentido, embora tenha havido divergência e distinção na fundamentação elencada. 
na Constituição brasileira, "reconheceram a união estável para casais do mesmo sexo" (SUPREMO TRIBUNAL FEDERAL, 2011).

Explicando: a ADI 4.277, originariamente apresentada como ADPF 178, pretendia o reconhecimento de que a união de duas pessoas do mesmo sexo pudesse, sim, integrar o conceito de família. Era também intento da referida ação a extensão do regime jurídico da união estável às uniōes homoafetivas. $\mathrm{Na}$ ADPF 132, foi sustentado que o fato de não se conhecer juridicamente a união homoafetiva é contrário à dignidade humana e viola os direitos fundamentais à liberdade e à igualdade, dentre outros.

Em 05/05/2011, no julgamento conjunto das demandas, cuja publicação no DJE ocorreu em 14/10/2011, e que teve como relator o Ministro Ayres Britto, o STF, após importante e extensa deliberação quanto à "questão da mais elevada significância social" (BRASIL, 2011, p. 723), reconheceu a que interpretação constitucional refuta qualquer sentido do artigo 1.723 do Código Civil que inviabilize ou impeça o reconhecimento da união estável entre pessoas do mesmo sexo.

Em que pese à decisão envolva inúmeras considerações e argumentos jurídicos, e todos mereçam destaque e citação, o que importa para este trabalho é demonstrar a construção hermenêutica realizada pelo STF, que, com o intuito de tutelar juridicamente a união estável homoafetiva, se valeu da chamada abertura material dos direitos fundamentais. Quer dizer, foi reconhecido direito fundamental originariamente não escrito na Constituição, in verbis:

A Constituição não interdita a formação de família por pessoas do mesmo sexo.
Consagração do juízo de que não se proíbe nada a ninguém senão em face de um direito
ou de proteção de um legítimo interesse de outrem, ou de toda a sociedade, o que não
se dá na hipótese sub judice. Inexistência do direito dos indivíduos heteroafetivos à
sua não-equiparação jurídica com os indivíduos homoafetivos. Aplicabilidade do $₫ 2^{\circ}$
do art. $5^{\circ}$ da Constituição Federal, a evidenciar que outros direitos e garantias, não
expressamente listados na Constituição, emergem "do regime e dos princípios por ela
adotados", verbis: "Os direitos e garantias expressos nesta Constituição não excluem
outros decorrentes do regime e dos princípios por ela adotados, ou dos tratados
internacionais em que a República Federativa do Brasil seja parte" (BRASIL, 2011,
p. 614).

Em resumo, ficou assentado que: (i) a hermenêutica constitucional veda o preconceito e a discriminação em razão do sexo e da opção sexual dos indivíduos; (ii) todos, independentemente do sexo ou opção sexual, têm direito à proteção da autonomia de vontade, da intimidade e da vida privada; (iii) o material positivado da "Carta Política" (expressão utilizada na decisão) não obriga e tampouco proíbe a fruição da sexualidade individual; (iv) as unióes homoafetivas têm direito a tratamento isonômico ao verificado nas heteroafetivas; (v) não há razóes e argumentos razoáveis que sustentem a diferenciação ou a proibição da tutela jurídica das unióes entre pessoas do mesmo sexo e muito menos a sua exclusão do conceito de família, em outras palavras, "não há no texto constitucional qualquer alusão ou mesmo proibição ao reconhecimento jurídico das uniōes homoafetivas" (BRASIL, 2011, p. 723); (vi) "este julgamento demonstra que ainda há uma longa trilha, que é permanente na história humana, para a conquista de novos direitos” (BRASIL, 2011, p. 695); (vii) "a extensão às unióes homoafetivas do mesmo regime jurídico aplicável à união estável entre pessoas de gênero distinto justifica-se e legitima-se pela direta incidência, 
dentre outros, dos princípios constitucionais da igualdade, da liberdade, da dignidade, da segurança jurídica [...] e do direito à busca da felicidade" (BRASIL, 2011, p. 844) ${ }^{22}$.

Assim, de toda a estrutura exemplificativa aqui exposta, retira-se a mesma conclusão a que chegou o Ministro Joaquim Barbosa (ao enfrentar os problemas da ADI 4.277 e a ADPF 132): "não podemos esquecer, por outro lado, que a própria Constituição estabelece que o rol de direitos fundamentais não se esgota naqueles expressamente por ela elencados" (BRASIL, 2011, p. 724-725). Isso porque "outros direitos podem emergir a partir do regime e dos princípios que ela própria, Constituição, adotou, ou dos tratados internacionais firmados pelo Brasil” (BRASIL, 2011, p. 724-725).

Cumprida a etapa ilustrativa, passar-se-á às considerações finais a respeito da pesquisa desenvolvida.

\section{DIREITO GLOBAL E DEMOCRACIA: AS NOVAS ROUPAGENS POLÍTICO- JURÍDICAS PROVENIENTES DA GLOBALIZAÇÃO}

Pôde-se perceber até o presente momento a importância do ente estatal na produção da norma jurídica. Em outros termos, o estudo até agora realizado revelou um duplo papel do ente estatal na tutela dos direitos fundamentais: (i) abster-se e (ii) efetivar tais direitos. É possível afirmar, a partir dessa constatação, que o ordenamento jurídico, como posto, somente será relevante enquanto a lei e demais fontes do direito forem capazes de produzir efeitos na sociedade (STAFFEN, 2015, p. 32).

Acontece que o advento da globalização oferece nova roupagem ao Estado e, por consequência, ao direito, à qual aqui se denominará direito global e/ou transconstitucionalismo.

$\mathrm{Na}$ verdade, teorizar acerca do elemento global do direito pressupóe adentrar ao fenômeno da globalização. Salienta-se, inicialmente, que a globalização modifica - espacial e temporalmente - as formas de resentação social (ZOLO, 2010, p. 16). Aliás, "a globalização econômica produz um processo de globalização jurídica por via reflexa” (p. 35), de modo que governar, hodiernamente, transcende questóes estatais. Em verdade, envolve assuntos militares, intergovernamentais (ONU, por exemplo), organismos regionais (Conselho Europeu), ONGs, dentre outros (STAFFEN, 2015, p. 36-37).

Note-se, nessa linha, que a emancipação globalizatória redefiniu a extensão e importância das influências exteriores, contribuindo, desse modo, para uma alternância global das formas de execução e controle do poder (ARCHIBUGI, 2008, p. 55-56).

\footnotetext{
22 É oportuna uma última explicação: o Ministro Gilmar Mendes, embora tenha acompanhado os demais ministros, preocupado com as surpresas juridicas que poderiam surgir da decisão paradigmática naquele momento sacramentada, apresentou fundamentos jurídico-argumentativos, em parte, distintos dos demais colegas de plenário. Nas suas palavras, "limito-me a reconhecer a existência dessa união [estável homoafetiva], por aplicação analógica, ou se não houver outra possibilidade, mesmo extensiva, da cláusula constante no texto constitucional, sem me pronunciar sobre outros desdobramentos" (BRASIL, 2011, p. 745). Em complemento, ele sustentou que "não se trata de ativismo judicial, mas de cumprimento da própria jurisdição constitucional" (BRASIL, 2011, p. 778). Em verdade, "trata-se de um estimulo constitucional para que, de fato, as mais diversas situações jurídicas que envolvem união entre pessoas do mesmo sexo venham a ser disciplinadas" (BRASIL, 2011, p. 803).
} 
Com efeito, a globalização e o capitalismo redefiniram o papel do Estado no controle do poder, tendo sido instituídos outros métodos de governança global (STAFFEN, 2015, p. 33). Ocorre que já não subsiste a concepção territorial de controle do poderio estatal. É dizer, o Estado não habita sozinho e com o mesmo protagonismo de antes a morada do poder e do controle social (ARNAUD, 2007, p. 03).

Lembre-se que ao se falar de globalização é crucial ter em mente de qual globalização se fala. E o que é mais importante: o seu estudo deve ser interdisciplinar, porquanto os diferentes modelos globalizatórios interagem entre si. Daí a constataçáo de que, por exemplo, o contexto econômico fomenta as transformaçóes do cenário jurídico (COTTORRELL, 2012, p. 340-372).

A partir desse contexto de mudanças globalizatórias, torna-se imprescindível repensar a imbricação entre o ordenamento jurídico e o Estado. Isto é, o elemento transnacional do direito já não mais de amolda ao modelo de poder centralizado. Insiste-se, se o Estado, que era, antes, o senhor da produção jurídica, não mais povoa o centro da relação de poder, é preciso também repensar a estrutura jurídica.

Nesse cenário, surge a ideia de direito global, a qual se divide em dois níveis: (i) assuntos nacionais internos de cada Estado; (ii) cenário transnacional, área global. Verdade seja dita, o direito para ser global exige alta cooperação entre seus agentes, em ambos os níveis (STAFFEN, 2015, p.40).

Significa isso que a dimensão global do direito não pretende erradicar a figura estatal, o que configura ponto central para a comprovação da hipótese defendida - a de que existe uma imbricação entre a abertura material dos direitos fundamentais e a noção de direito global. Isso porque se poderia sustentar que a tese da abertura material não tem interação com as premissas do direito global pelo fato deste último não prever questóes nacionais.

Contudo, conforme sustentando por Staffen, acima citado, o globalismo jurídico não nega o direito e os assuntos de cada país. Em verdade, sua manifestação se dá tanto em ambiente interno e global. Salta a evidência, portanto, que a hipótese é perfeitamente plausível, à medida que se sustenta na premissa de que é por uma abertura constitucional que direitos humanos e interesses globais passam a ser de interesse interno, o que corrobora para o desenvolvimento das noçóes de direito global.

Outra característica é que a política global é regida predominantemente por meio de networks, em que restam reduzidas as situações sob domínio e intermédio do Estado. Nesse contexto, as fontes do direito restam significativamente alargadas em vista da globalização jurídica. Significa isso que o transnacionalismo contribui para confusão entre as searas públicas e privadas (STAFFEN, 2015, p.50).

Contudo, as mudanças não estão adstritas às estruturas estatais. Na verdade, o transnacionalismo implica importantes reformulaçôes na atuação dos magistrados e dos tribunais. Quer dizer, julgar em campos transnacionais pressupôe vinculação à legalidade, ao dever de motivação das decisóes, coerência das decisões; justificação (distinguishing e overruling) e clareza e consistência nos argumentos (STAFFEN, 2015, p. 52).

Isso porque, retomando: o direito global baseia-se em normas setoriais; o espaço hierárquico é esvaziado; não há uniformidade; desaparece a linha que separa o âmbito público do privado; o contrato passa a receber o mesmo tratamento do que as disposiçóes legais e regulamentares; dever de observar a legalidade; possibilidade de discussóes em âmbito jurídico nacional serem reanalisadas por órgãos internacionais; o sistema é voltado a soluções do conflitos; o global adentra o nacional; a adesão não é vinculante, mas sim voluntária (STAFFEN, 2015, p. 53-54). 
Explica-se, ademais, que o fato de as instituições globais não terem sido eleitas não enfraquecem a democracia, haja vista que o direito global só se efetiva com a constante colaboração dos membros (STAFFEN, 2015, p. 53-55).

Além da relativização do poderio estatal, ou seja, da descentralização, o direito global dá azo à "capacidade de articulação social além da territorialidade estatal, doméstica, nacional” (STAFFEN, 2015, p. 64) 23

No direito global, portanto, não se fala mais em Estado de direito como tradicionalmente concebido. Fala-se, agora, em "espaços de direitos, nos quais a soberania dos Estados migra para os humanos" e para as instituições por ele formadas (STAFFEN, 2015, p. 68).

Adverte-se que um dos desafios advindos do direito global é a ocorrência de organizaçóes com interesses antidemocráticos, cujo combate somente é possível a partir do primado da participação e transparência da informação. Em linhas gerais, é o direito à participação e à transparência de informação que rompem com as barreiras e formalidades do direito sazonal, bem como garantem a efetividade de um sistema jurídico global (STAFFEN, 2015, p. 78).

No que tange á afirmação de que o transnacionalismo enfraquece, derrota ou torna a democracia obsoleta, em primeiro lugar, é preciso estabelecer de que viés democrático se está a analisar. É claro que a democracia (sentido lato) é afetada. Ao fim e ao cabo, a figura estatal foi redesenhada. Nesse contexto, o principal modelo fragilizado foi o modelo representativo (STAFFEN, 2015, p. 82-83) O problema da democracia representativa reside no esquecimento ou descuidado com o elemento humano. Enfraquece-se o humano, divide-se, a fim de consolidar interesses de dominação, ainda que por vias democráticas (STAFFEN, 2015, p. 85-86). Significa isso que o tranconstitucionalismo implica a emancipação do indivíduo e fragilização do estado e da sociedade (sazonal) o que redesenha também a democracia (STAFFEN, 2015, p. 87).

Em tempos transnacionais, o Estado e a sociedade, conforme concebidos alhures, devem ser substituídos pelo elemento humano. Trata-se aqui da retomada do homem ao status de personagem principal ou em níveis próximos de relevância. $\mathrm{O}$ direito global se coaduna com a democracia, uma vez que se sustenta nas premissas da cooperação/ participação e na (transparência) da informação. A verdade é que uma democracia que se quer verdadeira e efetiva não deve se fundar na igualdade, mas, especialmente, na tolerância (STAFFEN, 2015, p. 88).

Com efeito, faz-se preciso encontrar um termo médio, superando, com isso, o individualismo egoísta e o autoritarismo social, "manifestado na hegemonia das maiorias" (STAFFEN, 2015, p. 90). Portanto, uma democracia adaptada ao transnacionalismo pressupóe que as ideias de democracia direta e republicana dialoguem entre si (STAFFEN, 2015, p. 90).

A democracia, em ambiente transnacional, requer não somente a igualdade formal, mas, sobretudo, a igualdade de possibilidades de participação nas deliberaçóes envolvendo a coisa pública. Ou seja, a democracia transnacional deve pautar-se por expedientes diretos, cuja instrumentalidade se dê por novos canais que envolvam o homem e não apenas a abstração da sociedade. Acredita-se que esse modelo democrático é favorável no combate a

23 Um bom exemplo é a união MAP que quis participar das discussões sobre as obras do pacífico para integração de Bolivia, Brasil e Peru. A MAP conta com representantes dos três paises, que passaram a integrar a cooperação e integração entre os paises da Amazônia Sul-Ocidental (STAFFEN, 2015, p. 64). 
regimes tecnocratas (STAFFEN, 2015, p. 93). Trata-se de uma transcendência política, em que o homem assume o centro novamente.

A proposta do direito global não deve pretender aniquilar toda e qualquer exclusividade ou individualidade estatal. Na verdade, é necessário focar em uma ruptura do antigo modelo de freios e contrapesos da atuação estatal na satisfação dos direitos humanos (STAFFEN, 2015, p. 109).

\section{Considerações Finais}

Conforme visto, o conceito de direito contemporâneo, de vertente constitucionalista, distancia-se, até certo ponto, dos ideais jusnaturalistas e jurídico-positivistas de outrora. As exigências político-jurídicas de hoje são outras, sendo outro, também, o papel do Estado na realização e efetivação de direitos. Quer dizer, a transição dos modelos político-jurídicos, guardada a especificidade de espaço e tempo, demonstra a fragilidade e a inviabilidade das antigas formas de dominação e organização social.

Com efeito, o próprio advento do constitucionalismo, mormente a institucionalização dos direitos humanos no âmbito estatal interno - isto é: com o reconhecimento dos chamados direitos fundamentais -, inspirou novos contornos da relação entre o Estado e a sociedade. Nesse sentindo, salta à evidência a repercussão do Estado e das Constituiçóes, mas, também, do elemento transacional na criação e proteção dos direitos fundamentais. Em outros termos, não há direitos fundamentais sem algum tipo de representatividade, ainda que ela não tenha aquela roupagem arcaica de Estado.

Muito embora não seja simples conceituar os direitos fundamentais, a revisão bibliográfica desenvolvida neste trabalho forneceu os subsídios mínimos para a constatação de que esses direitos (a) possuem conceito extremamente dinâmico, que guarda relação com o contexto político, social e jurídico em que se desenvolveram; (b) têm como objeto de tutela a pessoa humana; (c) estão originariamente concatenados com o advento do Estado e das Constituiçôes; (d) destacam-se por sua natureza de positivação constitucional interna, o que, dentre outros aspectos, lhes diferencia dos direitos humanos; (e) representam, incialmente, mecanismos de defesa contra a tirania estatal, isto é, expressam garantias de proteção contra a intervenção do Estado na esfera da liberdade (e propriedade) individual; (f) obrigam, num segundo momento, o Estado a atuar de forma a concretizar as necessidades dos indivíduos na relação entre particulares, o que implica a imposição de reconhecimento, validade e concretização universal dos direitos fundamentais; (g) na contemporaneidade, influenciados pelo contexto democrático e pelos reflexos do segundo pós-guerra, garantem a esfera de autonomia do particular, bem como exigem deste o mínimo de responsabilidade político-jurídica, o transformando em verdadeiro ator social, o que imbrica diretamente com a ideia de globalismo jurídico.

Percebeu-se, ademais, que a positivação dos direitos fundamentais no texto constitucional inaugura um caráter duplo de fundamentação, formal e material, do qual a exegese constitucional vem reconhecendo direitos para além da simples expressão literal das disposiçóes constitucionais.

Partindo-se dos problemas ora formulados, pode-se concluir que o artigo $5^{\circ}$ da $\mathrm{CRFB} / 88$ bem representa a miscigenação de teorias jurídicas influentes no atual modelo de direito. Por um lado, fica evidente a influência legalista na escrituração taxativa dos direitos 
fundamentais. De outro, nota-se que o $\$ 2^{\circ}$ do aludido dispositivo constitucional, ao prever a abertura de reconhecimento material dos direitos fundamentais, remonta, de certa forma, aos ideais jusnaturalistas de outrora e, também, impulsiona a de um direito global.

Em outros termos, ora os dizeres constitucionais fecham a interpretação e aplicação do direito, ora flexibilizam-nas, denotando, ainda hoje, diferentes níveis de interferência moral no direito. Isto é, o sistema constitucional brasileiro, por ser pautado nos direitos fundamentais, é um sistema formal e material: fechado em alguns pontos, aberto e não absoluto noutros, o que permite a sua imbricação com a ideia de um direito global.

Circunstâncias essas que exigem um judiciário forte e com poderes, o que, todavia, não pode significar um judiciário ativista ou autoritário. Quer dizer, embora não tenha sido objeto específico de estudo, o trabalho não nega a possibilidade da materialização de direito pelos juízes e tribunais - o que decorre da própria natureza da ordem jurídica brasileira -, desde que sejam observados critérios de legitimidade e correção do exercício judicial.

Por derradeiro, a pesquisa procedida possibilita a afirmação de que em virtude da globalização o homem deixa de ser abstrato para ser concreto. Todavia, diante dos episódios de barbárie e de cenas de terrorismo, o elemento nacional tem ganhado novo folego, fazendo com o que, hodiernamente, o maior desafio dos direitos humanos seja o de construir uma arquitetura funcional apta a compatibilizar esses direitos com as noçóes de humanização e omninização.

Acredita-se, para fins de confirmação da hipótese defendida, que a abertura material dos direitos fundamentais desempenha papel fundamental na busca do citado objetivo, uma vez que é por meio dela que os direitos humanos e outros direitos fundamentais anteriormente não previstos são interiorizados no direito de determinado país, como no caso do Brasil.

Em última análise, ao permitir uma abertura - do tipo axiológica - esse instrumento constitucional acaba por impulsionar as premissas de um direito global, o qual, insiste-se deve ser entendido tanto numa perspectiva interna quanto externa.

\section{REFERÊNCIAS}

ALEXY, Robert. Teoria dos direitos fundamentais. Trad. de Virgílio Afonso da Silva da 5a edição alemã. São Paulo: Malheiros, 2011.

ARCHIBUGI, Daniele. The global commonwealth of citizens: toward cosmopolitan democracy. Princeton: Princeton University Press, 2008.

ARNAUD, André-Jean. Prefácio. In: ARNAUD, André-Jean; JUNQUEIRA, Eliane Botelho (Org.). Dicionário da Globalizaçáo: Direito - Ciência Política. Rio de Janeiro: Lumen Juris, 2006.

BOBBIO, Norberto. O positivismo jurídico: lições de filosofia do direito. Trad. de Márcio Pugliesi, Edson Bini e Carlos E. Rodrigues. São Paulo: Ícone, 2006.

BOBBIO, Norberto. Teoria do ordenamento jurídico. Trad. de Maria Celeste Cordeiro Leite dos Santos. 10. ed. Brasília: Editora Universidade de Brasília, 1999.

BRASIL. Constituição da República Federativa do Brasil de 1998. Disponível em: http://www.planalto.gov.br/ccivil_03/Constituicao/Constituicao.htm. Acesso em: 07 ago. 2017. 
BRASIL. Decreto-Lei 3.689, de 03 de outubro de 1941. Disponível em: http://www. planalto.gov.br/ccivil_03/decreto-lei/Del3689Compilado.htm. Acesso em: 07 ago. 2017.

BRASIL. Supremo Tribunal Federal. Ação direta de inconstitucionalidade no 939. Relator: Ministro Sydney Sanches. Julgado em 15/12/1993. Brasília/DF. Disponível em: http://redir.stf.jus.br/paginadorpub/paginador.jsp?docTP=AC\&docID=266590. Acesso em: 07 ago. 2017.

BRASIL. Supremo Tribunal Federal. Ação direta e inconstitucionalidade 4.277. Relator: Ministro Ayres Britto. Julgado em 05/05/2011. Brasília/DF. Disponível em: http:// redir.stf.jus.br/paginadorpub/paginador.jsp?docTP=AC\&docID=628635. Acesso em: 07 ago. 2017.

BRASIL. Supremo Tribunal Federal. Agravo regimental no mandado de injunção 772. Relator: Ministro Celso Mello. Julgado em 24/10/2007. Brasília/DF. Disponível em: http://redir.stf.jus.br/paginadorpub/paginador.jsp?docTP=AC\&docID=582646. Acesso em: 07 ago. 2017.

BRASIL. Supremo Tribunal Federal. Arguição de descumprimento de preceito fundamental 132. Relator: Ministro Ayres Britto. Julgado em 05/05/2011. Brasília/DF. Disponível em: http://redir.stf.jus.br/paginadorpub/paginador. jsp?docTP=AC\&docID=628633. Acesso em: 07 ago. 2017.

BRASIL. Supremo Tribunal Federal. Habeas Corpus 88. 420. Relator: Ministro Ricardo Lewandowski. Julgado em 17/04/2007. Brasília/DF. Disponível em: http://redir.stf. jus.br/paginadorpub/paginador.jsp?docTP=AC\&docID=46347220. Acesso em: 07 ago. 2017.

BRASIL. Supremo Tribunal Federal. Habeas Corpus 94.404. Relator: Ministro Celso Mello. Julgado em 18/11/2008. Brasília/DF. Disponível em: http://redir.stf.jus. br/paginadorpub/paginador.jsp?docTP=AC\&docID=612361. Acesso em: 07 ago. 2017.

BRASIL. Supremo Tribunal Federal. Recurso extraordinário 214.349. Relator: Ministro Moreira Alves. Julgado em 13/04/1999. Brasília/DF. Disponível em: http://redir. stf.jus.br/paginadorpub/paginador.jsp?docTP=AC\&docID=245337. Acesso em: 07 ago. 2017.

BRASIL. Supremo Tribunal Federal. Recurso extraordinário 297.901. Relatora: Ministra Ellen Gracie. Julgado em 07/03/2006. Brasília/DF. Disponível em: http://redir.stf. jus.br/paginadorpub/paginador.jsp?docTP=AC\&docID=260411. Acesso em: 07 ago. 2017.

BRASIL. Supremo Tribunal Federal. Supremo reconhece união homoafetiva. Disponível em: http://www.stf.jus.br/portal/cms/verNoticiaDetalhe.asp?idConteudo=178931. Acesso em: 07 out. 2015.

COTTORRELL, Roger. What is transnational law? Law \& Social Inquiry - Queen Mary University of London. London, n. 2, 2012.

CUNHA, Paulo Ferreira da. Do constitucionalismo global. Revista Brasileira de Direito Constitucional, v. 15. p. 245-255, jan.-jul. 2010. Disponível em: http://www. esdc.com.br/RBDC/RBDC-15/RBDC-15-245-Paulo_Ferreira_da_Cunha_(Do_ Constitucionalismo_Global).pdf. Acesso em: 08 out. 2015. 
DUQUE, Marcelo Schenk. Curso de Direitos Fundamentais: teoria e prática. São Paulo: Revista dos Tribunais, 2014.

GRIMM, Dieter. A função protetiva do estado. In: NETO, Cláudio Pereira de Souza; SARMENTO, Daniel (org.). A constitucionalizaçáo do direito: fundamentos teóricos e aplicaçóes específicas. Rio de Janeiro: Lumen Juris, 2007.

HOBBES, T. Leviatá ou Matéria, Forma e Poder de Estado eclesiástico e civil. Tradução de João Paulo Monteiro e Maria Beatriz Nizza da Silva 2a edição. São Paulo: Abril Cultural, 1983.

MIRANDA, Jorge. Manual de direito constitucional. 5. ed. Coimbra: Coimbra Editora, 2012.

MOLLER, Marx. Teoria geral do neoconstitucionalismo: bases teóricas do constitucionalismo contemporâneo. Porto Alegre: Livraria dos Advogados, 2011.

NEVES, Marcelo. Transnacionalidade do direito: novas perspectivas dos conflitos entre ordens jurídicas. 1. ed. São Paulo: Quartier Latin, 2010

NOVAIS, Jorge Reis. As restriçóes aos direitos fundamentais náo expressamente autorizadas pela constituiçáo. 2. ed. Coimbra: Coimbra Editora, 2010.

PARDO, David Wilson de Abreu. Direito Fundamentais náo enumerados - justificaçáo e aplicaçáo -. 2005. Tese (Doutorado em Direito) - programa de Pós-Graduação em Direito, Universidade Federal de Santa Catarina, Florianópolis, SC, 2005.

PIEROTH, Bodo; SCHLINK, Bernhard. Direitos Fundamentais. Trad. de Antônio Francisco de Souza e Antônio Franco. São Paulo: Saraiva, 2012.

QUEIROZ, Cristina M. M. Direitos Fundamentais. 2. ed. Coimbra: Coimbra Editora, 2010.

SARLET, Ingo Wolfgang. A eficácia dos direitos fundamentais. 6. ed. Porto Alegre:

Livraria do Advogado Editora, 2006.

SARLET, Ingo Wolfgang; MARINONI, Luiz Guilherme; MITIDIERO, Daniel. Curso de Direito Constitucional. São Paulo: Revista dos Tribunais, 2012.

STAFFEN, Márcio Ricardo. Globalismo jurídico. Perú: Egacal Editora, 2015.

VIEIRA, Oscar Vilhena. A constituiçáo e sua reserva de justiça: um ensaio sobre os limites materiais ao poder de reforma. São Paulo: Malheiros, 1999.

ZOLO, Danilo. Globalização: um mapa dos problemas. Tradução: Anderson Vichinkeski Teixeira. Florianópolis: Conceito Editorial, 2010.

\section{Fausto Santos de Morais}

faustosmorais@gmail.com

Doutor (2013) e mestre (2010) em Direito Público - UNISINOS (Capes 6), além de especialista em Direito Tributário - UPF (2006). Pesquisador na área da Hermenêutica Jurídica, Argumentação Jurídica, Direitos Fundamentais, Teoria do Direito, Direito Constitucional, e Direito e Literatura. Docente da Escola de Direito e do PPGD da Faculdade Meridional - IMED/Passo Fundo. Editor Chefe da Revista Brasileira de Direito - A1 Qualis 2017. Advogado. 


\section{José Paulo Schneider dos Santos}

josepauloschneider@yahoo.com.br

Mestrando em Direito, Democracia e Sustentabilidade do Programa de Pós-Graduação Stricto Sensu em Direito da Faculdade Meridional de Passo Fundo/RS. Bolsista PROSUP/ CAPES. Pós-graduado em Direito Penal e Processo Penal da Faculdade IDC, Porto Alegre/ RS. Graduado em Direito pela Faculdade Meridional de Passo Fundo/RS. Bolsista com apoio FAPERGS (2012-2015). Editor Assistente da Revista Brasileira de Direito - A1 Qualis 2017. Advogado.

\section{Guilherme Pavan Machado}

g.pavan.machado@gmail.com

Mestrando em Direito pela Faculdade Meridional IMED, na linha de pesquisa Fundamentais do Direito e Democracia. Membro do Grupo de Pesquisa: Direitos Fundamentais, hermenêutica e proporcionalidade: crítica ao desenvolvimento prático-teórico do dever de proteção aos Direitos Fundamentais. Bacharel em Direito pela Faculdade Meridional IMED. Advogado. 